\title{
IQTISHODUNA
}

IQTISHODUNA: Jurnal Ekonomi Islam

E-ISSN: 2443-0056, P-ISSN: 2252-5661

Accredited Sinta 2 Number 148/M/KPT/2020

Volume 10 Issue 2, October 2021

Journal Page is available to:

https://ejournal.iaisyarifuddin.ac.id/index.php/iqtishoduna

\section{The Economic Thought of Syeikh al Mutawalli Al-Sya'rawi from His Book of 'Tafsir Al-Sya'rawi'}

\author{
Mohd Shahid Bin Mohd Noh ${ }^{*}$ \\ ${ }^{1}$ Senior Lecturer, Department of Syariah and Economy, Faculty of Islamic Studies, Universiti
} Malaya, Malaysia

\begin{tabular}{l} 
ARTICLE INFO \\
\hline Article history: \\
Received April 26, 2021 \\
Revised September 13, 2021 \\
Accepted September 15, 2021 \\
Available online October 1, 2021 \\
Keywords: \\
al-Sya'rawi, economic thought, tafsir \\
Paper type: Conceptual paper \\
Please cite this article [Turabian of \\
style 8th edition]: Noh, Mohd Shahid \\
Bin Mohd. "The Economic Thought of \\
Syeikh al Mutawalli Al-Sya'rawi from \\
His Book of 'Tafsir Al- \\
Sya'rawi'" IQTISHODUNA: Jurnal \\
Ekonomi Islam [Online], Volume 10 \\
Number 2 (1 October 2021)
\end{tabular}

*Corresponding author

e-mail: shahid82@um.edu.my

Page: 1-16

\begin{abstract}
Syeikh al-Mutawalli al-Sya'rawi is a prominent muslim Egyptian scholar in his era. He had King Hammad Price as an appreciation on his contribution of ideas and thoughts towards islamic spiritual development and yet he became well known in Muslim world, particular in Arab countries through his tafsir lesson, where eventually been written and complied in volume of books, namely as Tafsir al-Sya'rawi. Besides producing the ideas on aqidah, feqh and tasawwuf, he also included in his words some of the economic thought were could be derived from his books and lectures. This paper aims to explore numbers of his economic thought mobilizing the analysis content methodology from his tafsir, particularly in Surah al-Baqarah. As a result, this study finds that he had shown consistent ideas in supportingshari'ah laws in promoting sadaqahandinfaq, sharingrizq, combatting gambling andriba, strengthening zakat roles and enforcing debt etiquette as mentioned in Al-Quran by giving economic reasons behind the elements said.
\end{abstract}

IQTISHODUNA with CC BY license. Copyright @ 2021, the author(s)

\begin{abstract}
Abstrak: Syeikh al-Mutawalli al-Sya' rawi adalah seorang ulama Mesir muslim terkemuka di zamannya. Dia memiliki Raja Hammad Price sebagai apresiasi atas kontribusi pemikiran dan pemikirannya terhadap pengembangan spiritual Islam, namun dia menjadi terkenal di dunia Muslim, khususnya di negaranegara Arab melalui pelajaran tafsirnya, yang pada akhirnya telah ditulis dan dituangkan dalam volume buku, yaitu sebagai Tafsir al-Sya' rawi. Selain menghasilkan pemikiran-pemikiran tentang aqidah, fegh dan tasawuf, ia juga memasukkan dalam kata-katanya beberapa pemikiran ekonomi yang dapat diambil dari buku-buku dan ceramah-ceramahnya. Tulisan ini bertujuan untuk menggali sejumlah pemikiran ekonominya yang memobilisasi metodologi analisis isi dari tafsirnya, khususnya dalam Surat al-Baqarah. Hasilnya, penelitian ini menemukan bahwa ia telah menunjukkan ide-ide yang konsisten dalam mendukung hukum syari'ah dalam mempromosikan sedekah dan infaq, berbagi rizki, memerangi perjudian dan riba, memperkuat peran zakat dan menegakkan etiket utang sebagaimana disebutkan dalam Al-Quran dengan memberikan alasan ekonomi. di belakang elemen kata.]
\end{abstract}

Kata kunci: al-sya' rawi, pemikiran ekonomi, tafsir. 


\section{INTRODUCTION}

Since religions encourages the numbers of moral conducts and good deeds to their followers such as in worship manner, etc, the economic activities are among the main concern because it embedded in human daily life in order for them to survive and achieve their needs ${ }^{1}$. One of the religion's functions is to flourish the moral sense of its believer by explaining right and wrong thing, those must be done and avoided ${ }^{2}$.

One of the undeniable fact that quotes the economic thought among human being had been existed since the early ages of the human history inspired by curious spirit in solving the emerging problem particularly in their social affairs $^{3}$. Nevertheless, this thought could only be found spreadly in the documents and records through the discussion in moral, politics and religions 4 . The modern economic

\footnotetext{
1 J. Barkley Rosser, "Belief: Its Role in Economic Thought and Economic Action," The American Journal of Economics and Sociology 52, no. 3 (1993): 355-368. https://www.jstor.org/stable/i277629.

2 Timur Kuran, "The Discontents of Islamic Economic Morality, American Economic Review," Papers and Proceedings of the Hundred and Eighth Annual Meeting of the American Economic Association, San Francisco 86, no. 2 (1996): 438-442.

${ }^{3}$ Munadi dan Iswanto, "The Concept Maslahah of Najamuddin Al Tufi and It's Relevance of Sharia Business," IQTISHODUNA: Jurnal Ekonomi Islam 9, no. 2 (2020): 151-166.

4 Mashum and Marlina, "Nusantara Syariah Economy (Construction of
}

thought
$\begin{aligned} & \text { was } \\ & \text { embarked } \\ & \text { progressively } \\ & \text { centuries }^{5} \text { in }\end{aligned}$

Abdul Sattar also elaborates the special criteria for Islamic economic thought as follow:

a. The idea of islamic economic comes from the reveals of AlQuran and hadith and teaching without referring to the sources as from the East of West civilizations.

b. Realizes the interests and needs of the public not merely relied on natural human instinct but to obey God's commands since human's opinions are not infallible, hence to refer God's judgment is a must especially in the event of dispute.

c. Optimization of the human energy is another criteria in islamic economic that could be comprehended from the various numbers of verses and hadiths. One of the hadith that denounced the act of beggar except in three conditions, a man who tested by God with chronic disease, man who also tested with natural disaster that destroyed his wealth and

Economic Cooperation between The Indonesian Muslim Community)," IQTISHODUNA: Jurnal Ekonomi Islam 9, no. 2 (2020): 197-224.

${ }^{5}$ Abdul Sattar, Al-Mabadi' Al-Asasiyah Li Al-Iqtisod Al-Islamiy (Beirut: Al-Motanabi Book Shop, 2009). 
man who bears a liability of a group of people and asked for help.

d. Islamic economic is not only encompassed on the statistic, numbers, graphs and charts for decision making, but most important thing to be highlighted and reflected is the role of behaviour of akhlaqin administrating the economy for the human wellbeing.

Therefore, religions and good moral conducts always associated with economic thought ${ }^{6}$.

\section{LIFE BACKGROUND AND HIS THOUGHT}

Syeikh Muhammad Mutawalli alSya'rawi was born on $17^{\text {th }}$ Rabi' althani $1329 \mathrm{H} / 1911$ in the small village named Daqadus, nearby to MayyitGhamr town in Daqhiliyyat province7. Raised in the religious family leaded by his pious father who worked as a farmer, but the character shown by him had influenced significantly in shaping

\footnotetext{
6 Syarifuddin and Kholis, "Towards Rahmatan Lil 'Alamin Economy (Analysis of Ukhuwah Islamiyah and Ashabiah for Economic Development in Medina)," IQTISHODUNA: Jurnal Ekonomi Islam 10, no. 1 (2021): 59-76.

7 Ahmad al-Mursi Husein Jauhar, AsySyaikh Muhammad Al-Mutawalli AsySya'râwồ (Imâm Al-'Ashr) (Kairo, Mesir: Nahdlah, 1990).
}

the noble deeds on al-Sya'rawi's personality ${ }^{8}$.

He had received early AlQuran education from Syeikh Abdul Majid Pasha who responsible in assisting him completed to memorize the holy book at his age of $11^{9}$. Then, he had completed his primary and secondary school in AlAzhar school, Zaqaziq before further his study to the faculty of Arabic language at Al-Azhar University in Cairo in 193710 .

Life in the middle of politic turmoil that experienced by Egypt from early $20^{\text {th }}$ century under the reign of monarchy royalty that ended with the revolution on 1952 succeeded by Jamal Abdul Nasir, and the environment of study in AlAzhar that evolved gradually, from traditional learning method to the new modern education system with standardized certification, had contributed in building his thought that lead to the designation of his tafsir ${ }^{11}$.

\section{THE METHODOLOGY USED IN TAFSIR AL-SYA'RAWI}

\footnotetext{
8 Istibsyarah, Hak-Hak Perempuan (Relasi Gender Menurut Tafsir Asy-Sya'rawi) (Jakarta: Mizan, 2004).

9 Ahmad al-Mursi Husein Jauhar, AsySyaikh Muhammad Al-Mutawalli AsySya'râwî̀ (Imâm Al-'Ashr).

10 Said Abu al-Ainain, Asy-Sya'rawi Alladzi Lâ Na'rifuh (Kairo: Akhbar al-Youm, 1995).

11 Hikmatiar Pasya, "Studi Metodologi Tafsir Al-Sya'rawi," Studia Quranika 1, no. 2 (2017): 141-154.
} 
Manhaj al-tafsir or methodological premise in quranic interpretation is a way utilized bymufassir in producing the understanding regarding to particular verse and chapter. According to Hikmatiar Pasya, al-Sya'rawi used two main methods in his tafsir, tafsir bi al-ra'y (opinion interpretation) and munasabahbain al-ayat (reconstruction of the verses).

Tafsir bi al-ra'y utilized by alSha'rawi is a normal methods used by manymufassirin in order to clarify the meaning behind the words or alQuran verses by referring to uniqueness of Arabic language. Then, he described using his own words in easier way to understand and elaborated suited to the level of public understanding 12 .

Second method is by linking the interpretation or explanation of one verses to another verses and hadith that related in meaning or topic discussed for the purpose of brighter understanding. For instance, when he interpreting the first verse of al-Fatihah, he referred to another verse in al-'Alaq, which means: "Recite in the name of your Lord who created"13, and also verse in Yunos : Say, "If Allah had willed, I would not have recited it to you, nor would He have made it known to you, for I had remained among you a lifetime before it. Then will

\footnotetext{
12 Ibid.

${ }^{13}$ Al-Quran, Al-'Alaq, 96:1.
}

you not reason?". At the end, he conluded that every muslim is no also urged to recite Bismillah only before embarking al-Quran recitation, but they are recommended to say the words in every single action we do as to express our gratitude to the gift of Allah and His uncountable bounties ${ }^{14}$.

In brief, the methodology used by al-Sya'rawi are not significantly different from another prominent mufassirinin enlightening the Al-Quran's meaning reflected to the new issues in economics, politics and scientific discovery. The effort shown had made his book one of the thickest tafsir book written in $20^{\text {th }}$ century.

\section{THE ECONOMIC THOUGHT IN} SPENDING AL-RIZQ

Regarding the topic of infaq fi sabil Allah, initially, al-

Sya'rawi liberalized the mean of alrizq whereas not only restricted on wealth or money in particular, but rizq or the bounties of Allah are anything that could benefit us in any form of contribution, the strength, knowledge, wisdom, etc ${ }^{1}$. Everything that contributes to the movement and mobilization of life (harakat al-hayat) is considered as rizqwhere it could be the reason and factor of wealth and mal generation ${ }^{15}$.

\footnotetext{
14 Muhammad Mutawalli al-Sya'rawi, Tafsir Al-Sya'rawi (Cairo: Mathobi' Akhbar al-Yaum, 1997).

${ }^{15}$ Ibid.
} 
He describes that when Allah created this world as a test place for us, Allah had created before that the support system of this life, all the creation which should serve human being as vicegerent of Allah and also the values existed in human being in nature that will guide them to utilize the bounties given in appropriate and objectively to fulfil their needs ${ }^{16}$. From this statement it clearly stated that the scarcity claimed by western economist is totally wrong ${ }^{17}$. But, vice versa, it was created in abundant and Allah may judge us on how we manage and channel the bounties as a guardianship, where it provides the clear platform for human being to be tested.

In another perspective, alSya'rawi also denounced gambling practice which he named as 'the easy rizq' where the profit comes from movements of others. So, it was prohibited due to the nature of the income that spoils the philosophy of income and gain that should be accompanied with effort and struggle ${ }^{18}$.

THE ECONOMIC THOUGHT IN ZAKAT

${ }^{16}$ Al-Sya'rawi. Vol.1, pp. 188-189.

17Muhammad Hifdil Islam, "Ibnu Taimiyah and His Concept of Economy," Iqtishoduna: Jurnal Ekonomi Islam 5, no. 1 (2016): 15-33.

${ }^{18}$ Al-Sya'rawi. Vol.1, pp. 222
Therefore, Islam encourages money or wealth mobilization by imposing zakat to any potentially growth wealth where it simultaneously urges the wealth owner to invest and grow their wealth through economic activities. By keeping the money idle, without paying zakat might be cursed by Allah in the hereafter, where in this world it may jeopardize the value of the money itself.

\section{Al-Sya'rawi commented \\ in elaborating zakat's roles} in muslim society in current economic condition that dominated by non-Muslim control, he said:

'The command of zakat is not merely to sacrifice small portions of our surplus income and wealth which are to be distributed among the recipients, but the message is to fulfil the gaps of deficit's unit in muslim society to the level that meet their neccesities and compulsory expenses in their life until make them free from begging to non-muslim or in particular, Jewish who provides loan in riba or usury. It in bigger scope shows the spirit

of ta'awun and takamul (cooperation and complemention) must be inculcated in muslim society besides aims to achieve the grant given by our prophet $(\mathrm{PBUH})$ was reported to say: There is no decrement in the wealth that used in donation' 2 .

Al-Sya'rawi shows his
awareness in building the
economic strength in muslim society


or the richness of the ummah in helping needy peoples not only for the sake of Allah, but in short term advantage, for the noble dignity of Islam as the vicegerent of Allah without relying on the loan that dominated in his era- almost 40 years ago- by conventional banking system organized and controlled by the Jewish merchant in riba-based transactions.

THE ECONOMIC THOUGHT IN SPENDING IN ALLAH'S WAYS (INFAQ FI SABIL LI ALLAH)

Al-Sya'rawi commented on the philosophy of giving some money or sadaqah to the recipients by clarifying the reason and wisdom behind that from the verse 254 Surah Al-Baqarah:

The meaning:

O you who have believed, spend from that which We have provided for you before there comes a Day in which there is no exchange and no friendship and no intercession. And the disbelievers they are the wrongdoers ${ }^{19}$.

The idea of wealth sharing actually had been addressed by many scholars and economist including Adam Smith, the tendency to voluntary action is born out of man's awareness of mutual interdependence. Self-interest itself leads one to help other people in time of need. Non-selfish behavior

\footnotetext{
${ }^{19}$ Al-Quran: Al-Baqarah. 2: 254.
}

is an integral part of human creation.

Allah never ask to spend on Allah,but spend out the wealth that have been given by Allah to you, because the wealth comes from human activities that need energy and material to perform the activities. All of these actions resulted from the plan inspired by human intellectual that created by whom creates the creation. Then, when all the human bodies are moving for the sake of producing wealth from activities using material created for it, everything definitely had been created by Allah ${ }^{20}$.

On top of that, he describes the varieties of the works and skills owned by different peoples is necessity that might create a needs one to another, or individual to the group and execute the duties of god's vicegerent is to build and construct this world ('imarah al'ardh). Therefore, the skills and abilities to produce work are not to be seemed as a rivalry but it is actually considered as a complimentary and pillar to the balance in the human life ${ }^{21}$.

The reason behind that is to avoid any individualistic life that may ruin the social relationship between human, but the weakness possessed by every human had

\footnotetext{
20al-Sya'rawi. 1418 H. Tafsir alSya'rawi. 2: 253.

${ }^{21} \mathrm{Al}-S y a$ 'rawi. Vol.2 . p. 1145.
} 
forced them to rely on another skills and knowledges and let the relationship being connected beyond the boundaries that allows the exchanges of knowledges in producing goodness.

He also explains that Allah explains this issue to human being by using two main mechanism, first, social dimension and second, economic dimension, whereby it may assist us to understand that the basic foundations of this existence are depended on that two main dimensions. It could be seen from our mind set that created by Allah where people always keep on thinking and planning in sparing their life in this world by two activities, creating food for economic reason, and marriage as for social reason ${ }^{22}$.

In relation with the statement above, every human being must strive for their life not limited and restricted on what they need, provided they must struggle and give the best they can in producing life maintenance, because the existence of unable people, week and old people as the needy group is inevitable in any society. By struggling the best of our effort, it may produce more wealth that could be used in helping the needy group. So, the dimension of society and economy are related each other

22Ibid. that lead to the balance of human life in society ${ }^{23}$.

In elaborating further verses relates to the sadaqah or donation, alSya'rawi describes that Allah always connects the word 'amwal' means wealth to pronoun of 'hum', that brings the meaning their wealth because it was produced by their energy and actions. Sometimes, Allah reminds us that the wealth in your possession is belonged to Allah, for instance in verse 33 Chapter Al-Nur:

\section{وآتوهم من مال الله الذي آتاكم}

The meaning: Yea, Give them something yourselves out of the means which Allah has given to you.

When we understand that in reality, the wealth actually is belonged to Allah and with His blessing, it was entrusted to us, so, if Allah asks us to spend some to the needy and other religious obligations, we must willingly ready to give up some of ours as asked by Allah. However, Allah asks the wealth to be given with the bounty of 'loan contract' where every time we spend Allah may reward with more in the future. In brief, more we give, more we will get ${ }^{24}$.

For the verse Al-Baqarah 261, he elucidated that the secret lies behind the command to share and

${ }^{23}$ Ibid.

${ }^{24}$ Ibid. 
spend wealth to others is to remind that every human have their limitation of energy, whereby the younger and energetic person who works today may transform to the weak and disabled guy in the future. Hence, by inculcating the culture of infaq fi sabilillah, everybody will fell ease where their needs might always be fulfilled by the assistance of others, and everybody might force themselves to spend some of their wealth with the awareness that the cycle of life might put people in the top for someday and at the bottom for another day, besides than hoping reward from Allah ${ }^{25}$.

This idea encourages the positive thinking and perceptions among people in society that comprised of wealthy, needy, rich and poor without any envy and hatred since everybody believes that the wealth the produced and possessed must be distributed to needy people where every one of them is not secured from that. Among the efforts done by welfare state such as Denmark in increasing its level of national happiness is by inequalities reduction in income distribution that allows lower income group also can enjoy the benefits provided by government.

For the verse 267 the same chapter when Allah urges muslim to give out the best of their wealth for donation, al-Sya'rawi comments that the wealth given should came from the good sources and conditions. In order to make the message clearer, he describes how dare the man who granted and gifted with the best skill and knowledge from Allah, then given with the high value of wealth from his effort, then he purposely chooses the worst thing to appreciate what Allah had bestowed to him?

From that, he summarizes the messages lie on these consecutive verses as follows:

1. Donation may not decrease the wealth instead in might be increased.

2. Donation given must not be nullified by harsh word

3. Best and gentle word better that donation accompanied with harsh word.

4. Donation must not be given for the sake of human but for Allah's love26.

The messages above are told by Allah as a cure to the disease that always disturbs muslim in performing donation and other generous activities such as greedy and worrying to an insufficient wealth in future. The main problems that overwhelmed the economic crisis especially sub-prime crisis 2008 that witnessed a major chaos in world economic history that affected more than a million people in America and Europe was believed came from moral hazard

${ }^{26} \mathrm{Al}-S y a$ 'rawi. op.cit. Vol.2 - p. 1162.

${ }^{25}$ Al-Sya'rawi. op.cit. Vol.2 . p. 1147. 
that associated with greediness of some financial institutions comprised of banking and insurance companies in maximizing their profit even though breaches the ethical in business deals.

Fayyad Hasanain support this idea of sharing the bounty of Allah among members in society by describing the special attributes introduced by shari'ahin economic practices is takaful or cooperation. The good performance of the society economy is indicated by the ability to fulfill the necessities of its member, particularly the poor group until there is no family or men abandoned without proper shelter, enough food, good healthcare and education system regardless of their achievement in import, export and other industries ${ }^{27}$.

The idea of takaful was also implemented in islamic insurance industry that known as as takaful. Recently, after focusing on CSR (corporate social responsibility) by corporate industries, the scholars and market players started to conduct varieties of philanthropy projects such as waqf model suggested by Azlizah Azrah, Rose Ruziana and Zurina Shafii and DompehDhuafa by Amelia Fauzia in effort to fill the gap between two major groups in society and

27 Fayyad Abdul Mun'im, "Simat AlNizhom Al-Iqtisod Al-Islamiy," Iefpedia, last modified 2018, www.iefpedia.com. simultaneously eliminates hatred and enmity between them.

Takaful or cooperation one to another also visualizes the spirit of muslim brotherhood as said by Allah in verse 10, chapter alHujuraat, that means :The believers are but brothers, so make settlement between your brothers. And fear Allah that you may receive mercy. Besides, there is also another verse that supports the idea of takaful, Allah says:The believing men and believing women are allies of one another. They enjoin what is right and forbid what is wrong and establish prayer and give zakahand obey Allah and His Messenger ${ }^{28}$.

Ibnu Khaldun also had explained in his book, al-Muqaddimah, about the benefits of mutual cooperation in community that might accelerate economic development and human progress by emphasizing the understanding of 'the needs contributed by a group always greater that an effort given by an individual'.

Sharing the wealth deemed in Islam as benevolent action where lies behind it the economic agenda to avoid the monopoly of the wealth for certain group in society and keep the gap between poor and rich in moderate level conversed to the capitalism that encourages the creation of unlimited individual wealth with no focus in bridging the

${ }^{28}$ AL-Taubah. Verse 71. 
gap, in order to realize the balance in economic distribution.

\section{THE ECONOMIC THOUGHT IN} RIBA

The prohibition of riba is agreed in consensus among the jurists in all madzhab. The reason of its prohibition could be summarized as below:

Those who consume interest cannot stand [on the Day of Resurrection] except as one stands who is being beaten by Satan into insanity. That is because they say, "Trade is [just] like interest." But Allah has permitted trade and has forbidden interest. So whoever has received an admonition from his Lord and desists may have what is past, and his affair rests with Allah. But whoever returns to [dealing in interest or usury] - those are the companions of the Fire; they will abide eternally therein.

Al-Sya'rawi connects the analogy described by the verse for riba consumer as man who could not stand properly resulted from the satan's bitten, same to this creation as we are witnessing now, the complete creation of universe with the creatures on it complement one to another, rely one to another by differentiating their skills, knowledges, exposures, variety of weathers, productions that would encourage the cooperation, complementation and reliance among human are always being revived and connected under the God's system ${ }^{29}$.

However, riba practice today definitely destructs the balance of the system created by Allah, the destruction makes the world in imbalance situation between the outside and inside realities where the most developed economic countries are also among the highest number of anxiety and depressed people living there ${ }^{30}$. Based on the statistics issued by National Institute of Mental Health (NIMN), 19.1 percent of adults in United States had experienced any anxiety disorder last year ${ }^{31}$

Economy crisis which hit America and some European countries affected a lot on people's lifestyle and mental health. Crisis that resulted from the sub-prime mortgage loan that associated with riba practice had brought negative impacts on economic such as inclination of unemployment rate, poverty and social deprivation that might stimulate mental health problems $^{32}$.

Accordingly, he clarifies that the instability, imbalances, chaos

${ }^{29} \mathrm{Al}-S y a$ 'rawi. op.cit. Vol.2 . p. 1188.

${ }^{30}$ Ibid.

31 "No Title," https://www.nimh.nih.gov/health/statisti cs/any-anxiety-disorder.shtml.

32 Wealth Health Organization, Impact of Economic Crisis on Mental Health (Conpenhagen: Who Office for Europe, 3AD). 
and crisis occurred today specifically in economic conditionsstimulated by instinct of human being that went deviant from the straight path where the wealth is seemed as a mean to realize life's needs not as an ultimate objective. However, riba made people accumulating wealth fundamentally for the figure and number whereas at initial it only used as a way to buy necessities and others, but after a mean was perceived as an objective, the system made by Allah might ruin and eroded ${ }^{33}$.

From the idea above, alSya'rawi surely observed the economic crisis happened at his time and what had Egyptian experienced after the war between Israel in 1973 or known as $10^{\text {th }}$ Ramadhan or $6^{\text {th }}$ October war. Hazem al-Beblawi studies the performance of Egypt's economy from 1974-2005, finds that Egypt showed poor economic achievement compared to the other East countries that moved better and faster. He also elucidates the constraints and impediments contributed to the problems notwithstanding the effort done in order to boost up the state economic condition $^{34}$.

Then, he refers to the words that witnessed the problems of

\footnotetext{
${ }^{33}$ Al-Sya'rawi. op.cit. Vol.2 . p. 1189.

34 Hazem al-Beblawi, Economic Growth in Egypt: Impediments and Constraints (Washington: The World Bank Publisher,
} 2008). ribasystem from western philosopher such as Hjalmar Schacht and John Maynard Keynes, where they observed the negative impacts on socioeconomic that allows rich group getting richer while poor family suffered with continuous poverty and difficulty.

From the perspective of moral values in society, al-'Sya'rawi uses the methodology of Al-Quran in simplifying the understanding with the analogy (al-tamthil), in this case he describes how the members of any society that approve and apply ribain their daily life could live in harmony and affection to others while rich group who usually owns the riba banking system charges additional payment as an exchange to the loan given to the poor who needs money assistance. He urges readers to think and imagine how the rich asks something that he does not need, at the same time, the borrower asked to pay what he does not own ${ }^{35}$. Otherwise, poor and needy people may always give their hatred sight to rich men who exploit them as economic deficit unit in society ${ }^{36}$.

Undoubtedly, the morality in economic thought and practices had been promoted before the era of prophet Muhammad even, for instance, Aristotle who known as the great Greek philosopher also described the importance of moral

\footnotetext{
${ }^{35}$ Al-Sya'rawi. op.cit. Vol.2 . p. 1190.

${ }^{36}$ Al-Sya'rawi. op.cit. Vol.2 . p. 1182.
} 
and behavior in conducting economic practices especially in the subjects of money values and usury when he denounced harshly riba practices in price determination and loan.

In this case, al-Sya'rawi correlates the importance of ethical economic practices to be applied in society by balancing the needs of the unit in the economy, whereas the needy group should be comforted by exempting them from any charges due to their difficulties and weaknesses. In long run, peace and stability of society is relied on how far the steadiness and relationship between the main group in it, rich, middle class and poor.

\section{THE ECONOMIC THOUGHT IN SPREADING GOODNESS THROUGH WEALTH SHARING}

There are number of verses

when Allah SWT urges muslimto share their excess wealth with others, in particular their relatives and close family members. One of the verses is verse 177, the meaning of Allah's words is:

Righteousness is not that you turn your faces toward the east or the west, but [true] righteousness is [in] one who believes in Allah, the Last Day, the angels, the Book, and the prophets and gives wealth, in spite of love for it, to relatives, orphans, the needy, the traveler, those who ask [for help], and for freeing slaves; [and who] establishes prayer and gives zakah; [those who] fulfill their promise when they promise; and [those who] are patient in poverty and hardship and during battle. Those are the ones who have been true, and it is those who are the righteous.

Through this verse, alSya'rawi viewed his opinion towards the importance of building the relationship through wealth sharing where the bounties whether it was given to the rich or poor came from Allah. Neglecting others in poverty overwhelmed by severe difficulties is a manifestation of inhumanity and lack of consideration. This humanity idea seemed as a reflection on what had been performed by the idea of capitalist and socialist during their golden reign by socialist Russian and capitalist of the western.

The introduction of welfare economy in the middle of $19^{\text {th }}$ century with the objectives to spread the wealth sharing between the surplus unit and deficit unit in the society, as shown by Thomas Hill Green who believes that human being is an agent to realize true freedom that was inspired by eternal consciousness by empowering the moral capability (Backhouse and Nisizawa, However, Yew Kwang Ng claims that the welfare economics only emphasizes on individual preferences instead of his welfare or happiness that make the theory deemed incomplete.

THE ECONOMIC THOUGHT IN DEBT 
The verse 282 in al-Baqarah chapter is the longest verse in this holy book. It describes in general about the rules, laws and ethics when someone dealing with debt from the aspects of recording, witnessing, some impediments and others.

According to al-Sha'rawi, the objective of the debt documentation as commanded in the verse, is to protect the right of borrower where the document will always remind his outstanding debt to pay in the future which may motivate him in working harder for the sake of debt payment other than fulfilling his family daily needs. By ignoring or forgetting his debt obligation might bring negative perceptions to the group of borrowers in society where it potentially leads to the denial of borrowing practice for the benefit of deficit unit in economy. Therefore, the trust between lender and borrower could be kept in good and support the nature of poor and rich living together in harmony and preserve the ecosystem of human life in one community ${ }^{37}$.

His view in this case is aligned with his idea pertinent to zakat in supporting the variety of human's destiny in the form of wealthy or not. Both stimulate the spirit of ta'awun (cooperation) among muslim and living hand to hand under the brotherhood of iman. The consistency of the thought was inspired by the depth

\footnotetext{
${ }^{37}$ Al-Sya' rawi. op.cit. Vol.2 . p. 1217.
}

understanding on the principles of imanand mukjizat.

Islam neither ask to break the gap between deficit and surplus unit in economy ecosystem by denying the individual ownership and make it equally in mandatory as promoted and enforced by socialism nor permits boundless wealth possession as done by capitalist, but Islam put the ownership of the wealth as in between socialist and capitalist $^{38}$. Therefore, in the debt practice, Islam does not command creditors to give up all the debt or give it benevolently, or chargeriba on the debt, but promoting the ethical and transparent debt relationship as mentioned in the verse.

\section{THE DISCUSSION}

1. According to the view of AlGhazali that emphasized on the preservation of five basic goals namely, religion, life, progeny, wealth and intellect by reflecting on their hierarchy as in sequences doruriyat (compulsories), hajiyat (neccesseties) and tahsiniyat (embellishment). He also recognized the first level of necessities are food, clothing and shelter as an indicator to fulfil the basic requirements of complete life

38 M. Ibrahim Birnawi, Khosois Wa Muqawwamat Al-Iqtisod Al-Islamiy (Medina: Majallah al-Jami'ah Islamiyah bi alMadinah al-Munawwarah, 1981). 
for anyone in society (M. Ghazanfar and A. Azim Islahi, 2003). From the discussion above, it is observed that al-Sya'rawi always mention about takaful or cooperation from whom Allah bestowed him with excess wealth, to assist the unlucky group by fulfilling their basic needs derived from the verse 267 Surah alBaqarah as an evidence of the significance roles contributed by the practice of infãqfíSabîlillah for a member in a community life.

2. The economy of humanity is among the obvious idea of alSya'rawi and it could be seemed in his focus on wealth sharing, negatives impacts of ribaand the needs of work to mobilize the human energy and skill.

3. The role of akhlãqor good behaviour in managing the economy is the most significance action to be inculcated and raised in national and international society where the majority of the financial crisis were caused by the human error particularly greediness and irresponsible acts in economic decision making.

4. The idea of harakat al-hayãt could be easily founded in his tafsir that brings the meanings of life ecosystem. When Allah creates human being in varieties of life status, namely, poor and rich, strong and weak, the wisdom behind it is to balance the ecosystem of human life by creating the needs of human to the work in effort to generate income. Works performed by human normally be done in collective manner, where the hierarchy of work leaded by directors followed by managers and workers is applied. This is the normal scene in every field of work that actually reflected to the needs of human being. Consequently, Al-Quran always urges people to share and spend their wealth by giving or creating income generation work in order to balance the ecosystem of life as called by alSya' rawiharakat al-hayãt.

The bounties and wealth that given to us shall be shared and distributed fairly among human in other to grant the balance in fulfilling human needs and necessities. Therefore, zakat is one of the tools that realizes the objectives, while the debt law in shari'ah also to ensure the wealth sharing process must be executed fairly, by providing the borrower with money and returning back the debt to the lender. This interaction in the society may stimulate the 
healthy economic circulation that reflects beyond the physical profit of any unit in the ecosystem, furthermore it may keep the sustainability of economic growth and development of the human civilization.

Diagram of Syeikh al-Sya'rawi's Thought in Economy

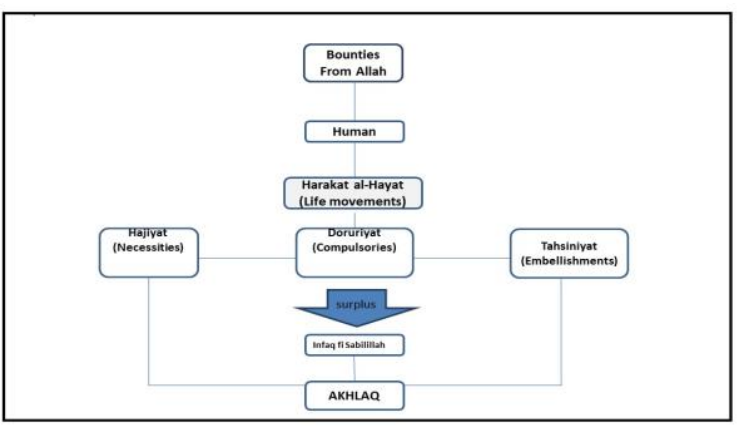

Diagram 1: Author's own

\section{CONCLUSION}

The roles of Al-Quran as the last testament is obviously monitored by relating the meanings or interpretations of the Book with the current issues happening today. As the continuous effort shown by previous scholars in writing tafsir across the centuries, al-Sya'rawi beautified the method of tafsir writing by connecting the verses and their meanings with the current problems with the possible suggestions that could be practiced by muslim. The scholastic idea of alSya'rawi definitely had revived muslim's views towards Al-Quran that not restricted only for the worships related matters, but inclusive the bigger scope of discussion to the health economic system and the practices that embedded in it. Undoubtedly, the scholarship of al-Sya'rawi was recognized globally in Islamic thought in general albeit the opinions expressed were not as detail as needed by economist with statistical and numerical based, it is sufficient for the practitioners, regulators as well as any individual to hold his idea as guidance according to the Al-Quran's teaching and preferences. 


\section{REFERENCE}

Ali, Muhamad Daud dan Habibah Al-Hiti, Abdul Sattar Ibrahim. 2009. AlMabadi' al-Asasiyah li al-Iqtisod al-Islamiy. Beirut: Al-Motanabi Book Shop.

Ahmad al-Mursi Husein Jauhar, Asy-Syaikh Muhammad al-Mutawalli asySya'râwwî

(Imâm al-'Ashr), Kairo, Mesir: Nahdlah, 1990,

Amelia Fauzia, 2017, Islamic Philanthropy in Indonesia: Modernization, Islamization and Social Justice. Austrian Journal of South-East Asian Studies, 10(2), 223-236.

Azliza Azrah Mohd Zakaria, Rose Ruziana Abd. Samad and Zurina Shafii, 2013, Venture Philanthropy Waqf Model: A Conceptual Study, Jurnal Pengurusan, (2013) 119 - 125.

Hazem al-Beblawi. 2008. Economic Growth in Egypt: Impediments and Constraints (1974-2204). Washington: The World Bank Publisher.

Hikmatiar Pasya, 2017, Studi Metodologi Tafsir al-Sya'rawi, Studia Quranika, Vol. 1, No. 2, Januari 2017, ms.141-154

Istibsyarah, Hak-hak Perempuan (Relasi Gender Menurut Tafsir asy-Sya'rawi) , Jakarta:Mizan, 2004.

Walid Mustafa Syawish, 2011, Al-Siyasah al-Naqdiyah Baina al-Figh alIslamiy wa al-Wadh' al-Iqtisodiy, Virgina: International Institute of Islamic Thought.

Hussain Umar, 1994, Tatawwur al-Fikr al-Iqtisodiy Qadiman wa Hadisan wa Mu'asiran, Kaherah: Dar al-Fikr al-'Arabiy, ms 36-38.

Islam, Muhammad Hifdil. 2016. "Ibnu Taimiyah and His Concept of Economy." Iqtishoduna: Jurnal Ekonomi Islam 5 (1): 15-33.

J.Barkley Rosser Jr., 1993, Belief: Its Role in Economic Thought and Economic Action, The American Journal of Economics and Sociology, Vol.52, No.3 (Jul.,1993), pp. 355-368.

M. Azhar Hussain, 2014. The Robustness of High Danish National Happiness: A Temporal Cross-Country Analysis of Population Subgroups. Social Indicators Research, Vol. 118, No.2 (September 2014), pp. 759-774.

M.Shaoqi al-Fanjari, n.d, Al-Islam wa al-Tawazun al-Iqtisodiy Baina al-Afrad wa alDuwal. Egypt: Al-Awqaf Minister Publisher.

M. Ibrahim Birnawi, 1981, Khosois wa Muqawwamat al-Iqtisod al-Islamiy, Medina: Majallah al-Jami'ah Islamiyah bi al-Madinah al-Munawwarah. P. 213214.

M.Umer Chapra, 2001, Islamic Economic Thought and The New Global Economy. Islamic Economic Studies, Vol.9, No.1, September 2001, p.6.

Mashum, AM Hafidz, and Marlina. 2020. "Nusantara Syariah Economy (Construction of Economic Cooperation between The Indonesian Muslim Community)." IQTISHODUNA: Jurnal Ekonomi Islam 9 (2): 197-224. 
Muhammad Mutawalli al-Sya'rawi, 1997, Tafsir al-Sya'rawi, Cairo: Mathobi' Akhbar al-Yaum.

Munadi, and Budi Iswanto. 2020. "The Concept Maslahah of Najamuddin al Tufi and It's Relevance of Sharia Business." IQTISHODUNA: Jurnal Ekonomi Islam 9 (2): 151-166.

Roger E. Backhouse and Tamotsu Nisizawa, 2006, Introduction: Reintrepreting The History of Welfare Economics, Retrieved from http://www.econ.ryukoku.ac.jp/ komine/hope/backnishi0612.pdf on August 2018.

Said Abu al-Ainain, Asy-Sya'rawi Alladzi Lâ Na'rifuh, Kairo: Akhbar al-Youm, 1995, ms. 28-29.

Syarifudin, Moh, and Nur Kholis. 2021. "Towards Rahmatan lil 'Alamin Economy (Analysis of Ukhuwah Islamiyah and Ashabiah for Economic Development in Medina)." IQTISHODUNA: Jurnal Ekonomi Islam 10 (1): 59-76.

Timur Kuran, 1996, The Discontents of Islamic Economic Morality, American Economic Review, Vol.86, No.2, Papers and Proceedings of the Hundred and Eighth Annual Meeting of the American Economic Association, San Francisco, CA, January5-7,1996(May,1996), pp.438-442.

Wealth Health Organization, 2011, Impact of Economic Crisis on Mental Health, Conpenhagen: Who Office for Europe, p.3.

Yew Kwang Ng. 2003. From preference to Happiness: Towards A More Complete Welfare Economics. Social Choice and Welfare. Journal. (2003) 20: 307-350. Berlin: Springer Verlag. 